\title{
Komunikasi Krisis Pemerintahan \\ (Studi Kasus Pada Biro Hubungan Masyarakat Sekretariat Daerah Provinsi Riau Pasca Kasus Suap Annas Maamun Tahun 2014)
}

\author{
Dwi Gayatri Mistara, Mutia Dewi ${ }^{b}$
}

\author{
aMahasiswa Ilmu Komunikasi Universitas Islam Indonesia, Yogyakarta, Indonesia, \\ +6282221422969, dwigytri@gmail.com \\ ${ }^{b}$ Dosen Pengajar Ilmu Komunikasi Universitas Islam Indonesia, Yogyakarta, Indonesia, \\ +62817200283, mutiaawel@gmail.com
}

\begin{abstract}
Abstrak
Annas Maamun sebelumnya terpilih menjadi Gubernur Provinsi Riau selama periode 20142019. Pada 25 September 2014, Annas Maamun ditangkap oleh Komisi Pemberantasan Korupsi (KPK) karena menerima suap sebagai usulan untuk menerima revisi konversi hutan di Kuantan Singingi, Riau seharga Rp. 2 miliar. Fakta tersebut menjadikan Pemerintah Provinsi Riau berada dalam situasi krisis. Penelitian ini bertujuan untuk memberikan penjelasan bagaimana Biro Humas Sekretariat Daerah Provinsi Riau melaksanakan kegiatan komunikasi krisis. Dengan menggunakan pendekatan kualitatif, penelitian ini berusaha menjelaskan beberapa cara untuk menangani krisis. Selain itu, juga akan dijelaskan beberapa faktor pendukung dan penghambat komunikasi krisis. Faktor pendukung diantaranya adalah menggunakan sistem komunikasi satu gerbang, menyediakan saluran tatap muka seperti reporter ruangan khusus, strategi pesan yang ditujukan untuk menunjukkan kepedulian, dan memaksimalkan saluran media massa. Sementara itu, untuk faktor penghambatnya, adalah rencana krisis tidak memiliki SOP tetap, isolasi PR di awal krisis, respon krisis yang tidak segera, tim komunikasi krisis yang tidak terstruktur, dan saluran komunikasi daring yang tidak digunakan secara optimal dan kehadiran juru bicara eksternal.
\end{abstract}




\begin{abstract}
Annas Maamun was previously chosen to become the Governor of Riau Province during the period of 2014-2019. On September 25th 2014 Annas Maamun was arrested by Indonesian Corruption Eradication Commission (KPK) due to for accepting bribes as a propose to accept revision of forest conversion in Kuantan Singingi, Riau for Rp. 2 billions worth. That fact converted the Government of Riau Province into crisis. This research developed aims to provide an explanation on how Public Relations Bureau of the Regional Secretariat of Riau Province implemented an activity of crisis communication. Using qualitative descriptive this research clarified if there are several ways in handling the government crisis communications. Furthermore, several enabling and inhibiting factors were identified as well. Enabling factors are using one gate communication system, providing face to face channel such a special room reporters, the strategy of delivered messages which is the rebuilding of showing up for caring action, and mass media channel maximally provided. Whilst, for the inhibiting factors are the crisis plan has not fixed rule, the public relations' position at the early stage of crisis was isolating itself, crisis respond was not immediately, unstructured crisis communication team, the communication online channel was not optimally used and the presence of external spokesman.
\end{abstract}

\title{
Keywords : Bribery, Crisis, Crisis Communication, Public Relations Bureau
}

\section{Pendahuluan}

Annas Maamun adalah Gubernur Riau terpilih periode 2014-2019. Sebelumnya, Annas Maamun menduduki posisi sebagai Bupati Rokan Hilir selama dua periode, yakni periode 2006-2013. Setelah menerima mandat sebagai Gubernur Riau pada 2014, Annas Maamun tersangkut kasus korupsi di awal masa pemerintahannya. Annas Maamun terlibat kasus suap senilai Rp. 2 Miliar terkait dengan proses alih fungsi 140 hektare lahan kebun sawit di Kabupaten Kuantan

Riyan Novitra, "Rekam Jejak Kasus Korupsi Gubernur Riau," https://m.tempo.co/read/news/2014/09/28/063 610246/rekam-jejak-kasus-korupsi-gubernurriau (diakses 23 Maret 2016).
Singingi, Riau. Berdasarkan kasus tersebut, Annas Maamun kemudian ditetapkan sebagai tersangka melaluioperasi tangkap tangan yang dilakukan oleh tim KPK. Operasi tangkap tangan tersebut dilakukan pada tanggal 25 September 2014, pukul 17.00 WIB. Lokasi penindakan ialah berada di Kompleks Citra Grand RC Blok 3 Nomor 2, Cibubur, Jakarta Timur. ${ }^{1}$

Annas Maamun kemudian dituntut hukuman pidana enam tahun penjara. ${ }^{2}$ Tuntutan tersebut kemudian

Rio Kuswandi, "Gubernur Annas Maamun Dituntut 6 Tahun Penjara," http://regional.kompas.com/read/2015/05/25/1 2304701/Gubernur.Annas.Maamun.Dituntut.6 Tahun.Penjara (diakses 23 Maret 2016). 
mengakibatkan timbulnya beberapa dampak. Di antaranya ialah APBD 2014 yang anjlok dan RAPBD 2015 ditolak oleh Kementerian Dalam Negeri Republik Indonesia (Riau Pos, 11 November, 2014). Hingga akhirnya, menimbulkan dampak negatif bagi operasional instansi pemerintahan dan menyebabkan krisis. Oleh karena itu, perlu untuk dilakukan beberapa tindakan komunikasi krisis. Komunikasi krisis sendiri merupakan suatu ragkaian kegiatan mulai dari tindakan pengumpulan, pengolahan, hingga penyebaran informasi yang dibutuhkan untuk mengatasi situasi krisis yang sedang terjadi (Kriyantono, 2015: 244-245). Penelitian ini kemudian berfokus pada tindakan komunikasi krisis yang dilakukan oleh Pemerintah Provinsi Riau melalui Biro Hubungan Masyarakat Sekretariat Daerah Provinsi Riau.

Biro Hubungan Masyarakat Sekretariat Daerah Provinsi Riau melakukan beberapa kegiatan dengan berlandaskan pada tugas pokok dan fungsi yang telah ditentukan. Dalam tugas pokok dan fungsi Biro Hubungan Masyarakat Sekretariat Daerah, disebutkan bahwa Biro Hubungan Masyarakat bertugas untuk melakukan kegiatan di bidang kehumasan (Peraturan Daerah Provinsi Riau Nomor 1 Tahun 2014, pasal 22). Di samping itu, Biro Hubungan Masyarakat Sekretariat Daerah Provinsi Riau juga merupakan salah satu staff pemerintahan yang memiliki keterkaitan erat dengan penanganan krisis pemerintahan. Hal tersebut sesuai dengan Peraturan Gubernur Riau Nomor 10 Tahun 2015 tentang Rincian Tugas, Fungsi dan Tata Kerja Sekretariat Daerah Provinsi Riau Pasal 138-149.

Pemerintah Provinsi Riau juga menarik untuk diteliti dikarenakan pada beberapa periode pemerintahan Provinsi Riau seringkali terjadi kasus penyuapan dan korupsi yang dilakukan oleh para pemimpinnya. Di antaranya ialah kasus korupsi yang dilakukan oleh Saleh Djasit (Gubernur Riau periode 1998-2003), Rusli Zainal (2003-2008 \& 2008-2013), dan terakhir ialah Annas Maamun (Gubernur Riau periode 2014-2019). Terkait permasalahan yang dihadapi oleh Pemerintah Provinsi Riau tersebut, maka rumusan masalah dalam penelitian ini adalah (1) Bagaimana komunikasi krisis yang dilakukan oleh Pemerintah Provinsi Riau untuk menghadapi krisis tersebut ?; (2) Bagaimana faktor pendukung dan penghambat dalam pelaksanaan komunikasi krisis tersebut?

\section{Metode Penelitian}

Penelitian mengenai Komunikasi Krisis Pemerintahan (Studi Deskriptif Kualitatif pada Biro Hubungan Masyarakat Sekretariat Daerah Provinsi Riau Pasca Kasus Suap Annas Maamun 2014) menggunakan metode penelitian deskriptif kualitatif sebagai jenis penelitian yang ditujukan untuk mendeskripsikan suatu 
fenomena yang terjadi tanpa dilakukan manipulasi ataupun rekayasa sehingga data yang disajikan sesuai dengan kondisi sesungguhnya (Sukadimanta, 2011: 73). Penelitian dilakukan dengan berfokus pada Biro Hubungan Masyarakat Sekretariat Daerah Provinsi Riau dan menggunakan beberapa metode pengumpulan data. Adapun di antaranya melalui metode pengamatan/observasi, wawancara, penelusuran dokumen, penelusuran berita media cetak lokal, dan penelusuran data online. Kemudian, data yang telah berhasil dikumpulkan oleh peneliti dianalisis dengan melakukan beberapa tahapan, yakni melakukan reduksi data terlebih dahulu, lalu penyajian data, hingga penarikan kesimpulan dan verifikasi.

\section{Analisis dan Pembahasan}

1. Krisis yang Terjadi pada Periode Kepemimpinan Annas Maamun Tahun 2014

a. Jenis Krisis

Pemerintah Provinsi Riau
mengalami krisis ketika Gubernur
Riau Periode 2014-2019 ditangkap
oleh KPK dimana terdapat ciri-ciri
krisis yang teridentifikasi pada kasus
suap yang dilakukan yakni sebagai
berikut.

1) Tidak Dapat Dihindari

Terjadinya Operasi Tangkap Tangan (OTT) terhadap Annas Maamun pada 25
September 2014 oleh Komisi Pemberantasan Korupsi. Ini merupakan salah satu kejadian yang tidak dapat dihindari oleh instansi pemerintahan. Pemerintah Provinsi Riau tidak memprediksi, menduga, dan tidak mengharapkan kejadian tersebut terjadi sehingga krisis pun tidak dapat dihindari oleh Pemerintah Provinsi Riau era kepemimpinan Annas Maamun.

2) Menciptakan Ketidakpastian Informasi Krisis yang terjadi menciptakan ketidakpastian informasi. Hal tersebut dikarenakan lokasi penangkapan yang tidak berada di ruang lingkungan Pemerintah Provinsi Riau sehingga perolehan informasi sedikit terkendala. Hingga pada munculnya juru bicara di luar pemerintahan, yang menyebabkan informasi menjadi simpang siur. Ketidakpastian informasi tersebut kemudian menyebabkan krisis semakin berkembang.

3) Menimbulkan Kepanikan dan Keterkejutan

Adanya kepanikan dan keterkejutan yang dirasakan oleh seluruh staff pemerintahan akibat dari terjadinya penangkapan Annas Maamun tersebut. Di samping itu, staff pemerintahan secara keseluruhan juga tidak memiliki persiapan untuk menangangi situasi krisis sehingga semakin menimbulkan kepanikan bagi operasional instansi pemerintahan. 
4)Menimbulkan Dampak Negatif bagi Operasional Organisasi

Krisis yang terjadi akibat penangkapan Annas Maamun karena menerima suap tersebut kemudian menimbulkan berbagai dampak negatif bagi operasional organisasi. Dampak negatif tersebut diantaranya laju perkembangan sistem pemerintahan yang menurun akibat terkendala kewenangan Plt. Gubernur Riau, juga APBD 2014 yang anjlok dan RAPBD 2015 yang ditolak oleh Kementerian Dalam Negeri RI sehingga menyebabkan krisis semakin meluas.

Di samping itu, krisis yang menimpa Pemerintah Provinsi Riau akibat dari kasus operasi tangkap tangan Annas Maamun selaku Gubernur Riau periode kepemimpinan 2014-2019 adalah krisis manajemen dan perilaku karyawan. Kriyantono (2015: 107) menyebutkan bahwa krisis manajemen dan perilaku karyawan "terjadi karena kelompok manajemen gagal melaksanakan tanggung jawabnya." Jenis krisis ini kemudian melihat perilaku manajemen dan karyawan sebagai titik utama permasalahan. Dalam kasus suap yang melibatkan Annas Maamun terkait dengan pengajuan revisi alih fungsi hutan di Kuantan Singingi Riau, memperlihatkan bahwa adanya tindakan yang menyalahi aturan dan tanggung jawab serta kewenangan yang dimiliki oleh seorang gubernur.

\section{b. Tahapan Krisis}

Krisis memiliki beberapa tahap, yakni prakrisis, krisis dan pascakrisis. Adapun tahapan krisis yang terjadi pada Pemerintah Provinsi Riau dapat dilihat pada tabel 1.

Tabel 1

Tahap-Tahap Krisis Pemerintah Provinsi Riau

\begin{tabular}{|c|c|c|c|}
\hline No. & Waktu & Peristiwa & Tahap Krisis \\
\hline 1. & Tahun 2003 & $\begin{array}{l}\text { Kasus korupsi yang menimpa Gubernur Riau } \\
\text { Periode 1998-2003, Saleh Djasit. }\end{array}$ & Prakrisis \\
\hline 2. & Tahun 2013 & $\begin{array}{l}\text { Kasus korupsi yang menimpa Gubernur Riau } \\
\text { Periode 2003-2008 dan 2008-2013, Rusli Zainal. }\end{array}$ & Prakrisis \\
\hline $3 .$. & 25 September 2014 & $\begin{array}{l}\text { Dugaan Annas Maamun menerima suap hingga } \\
\text { KPK menangkap Annas Maamun dan melakukan } \\
\text { pemeriksaan serta penahanan. }\end{array}$ & Prakrisis \\
\hline 4. & 26 September 2014 & $\begin{array}{l}\text { Annas Maamun ditetapkan sebagai tersangka dan } \\
\text { menjalani pemeriksaan lebih lanjut oleh KPK. }\end{array}$ & Krisis \\
\hline 5. & $\begin{array}{l}27 \text { September - } 1 \text { Oktober } \\
2014\end{array}$ & $\begin{array}{l}\text { Terjadi demonstrasi oleh mahasiswa/i universitas } \\
\text { di Riau. }\end{array}$ & Krisis \\
\hline 6. & $\begin{array}{l}30 \quad \text { September }-18 \\
\text { November } 2014\end{array}$ & $\begin{array}{l}\text { Saksi-saksi terkait kasus Annas Maamun diperiksa } \\
\text { oleh KPK baik dari lingkungan pemerintahan dan } \\
\text { swasta. }\end{array}$ & Krisis \\
\hline 7. & 25 November 2014 & $\begin{array}{l}\text { Dilakukan rekonstruksi kasus suap Annas } \\
\text { Maamun. }\end{array}$ & Krisis \\
\hline
\end{tabular}




\begin{tabular}{|c|c|c|c|}
\hline No. & Waktu & Peristiwa & Tahap Krisis \\
\hline 8. & $\begin{array}{l}11 \quad \text { Oktober } \\
\text { Desember } 2014\end{array}$ & $\begin{array}{l}\text { Sebagian program pemerintahan yang } \\
\text { dicanangkan oleh Annas Maamun tidak dapat } \\
\text { dilanjutkan karena terkendala permasalahan } \\
\text { kewenangan Annas Maamun. }\end{array}$ & Krisis \\
\hline 9. & 22 Desember 2014 & Gelar sidang perkara kasus suap Annas Maamun. & Krisis \\
\hline 10. & $\begin{array}{l}25 \text { Desember } 2014 \\
\text { sekarang }\end{array}$ & $\begin{array}{l}\text { Pemerintah Provinsi Riau melakukan publikasi } \\
\text { positif kepada masyarakat melalui website resmi } \\
\text { Biro Hubungan Masyarakat Setda Provinsi Riau } \\
\text { hingga menjalin kerjasama dengan KPK. }\end{array}$ & Pascakrisis \\
\hline 11. & 2 Januari 2015 - sekarang & $\begin{array}{l}\text { Kasus suap Annas Maamun mulai jarang } \\
\text { diberitakan di media massa. }\end{array}$ & Pascakrisis \\
\hline
\end{tabular}

c. Strategi Komunikasi Krisis Biro Hubungan Masyarakat Sekretariat Daerah Provinsi Riau

Strategi komunikasi krisis penting untuk dilakukan agar krisis tidak semakin meluas. Berikut tindakan komunikasi krisis yang telah dilakukan Biro Hubungan Masyarakat Sekretariat Daerah Provinsi Riau.
1) Menetapkan
pengelola
komunikasi krisis

Terdapat beberapa bagian-bagian yang ditetapkan oleh Kepala Biro Hubungan Masyarakat Sekretariat Daerah Provinsi untuk mengelola komunikasi krisis. Adapun bagianbagian tersebut ialah (1) Kepala Biro;

(2) Bagian Pengumpulan Informasi;

(3) Subbagian Pendataan Informasi;

(4) Subbagian Hubungan Pers; dan (5) Subbagian Bina Pemberitaan.

2) Menghubungi media massa terkait krisis yang terjadi

Biro Hubungan Masyarakat

Sekretariat Daerah Provinsi Riau melalui Subbagian Hubungan Pers menghubungi media massa untuk memberikan informasi terkait krisis yang terjadi. Adapun beberapa informasi yang disampaikan melalui media massa diantaranya sebagai berikut.

a) Informasi mengenai kasus yang terjadi. Berupa penjelasan kasus suap Annas Maamun, kepentingan Annas Maamun berpergian ke Jakarta sehingga terjadi operasi tangkap tangan oleh KPK, siapa yang terlibat dalam kasus tersebut, serta beberapa pernyataan terkait dengan kasus yang terjadi.

b) Informasi mengenai tindakan yang telah dilakukan. Berupa pernyataan resmi yang disampaikan oleh Biro Hubungan Masyarakat Sekretariat Daerah Provinsi Riau terkait kasus yang terjadi, seperti menyampaikan bahwa pemerintah segera memberikan bantuan hukum bagi Annas Maamun serta menyampaikan seluruh kegiatan positif yang dilakukan saat krisis 
tejadi, seperti menjalin kerjasama dengan KPK dan membuka layanan informasi publik.

c) Pernyataan yang memuat keprihatinan Biro Hubungan Masyarakat Sekretariat Daerah Provinsi Riau atas kasus yang terjadi hingga mengajak masyarakat Provinsi Riau untuk memaafkan tindakan yang telah dilakukan oleh Annas Maamun dan memberikan pesan agar masyarakat tidak mudah terprovokasi serta menjaga suasana tetap kondusif.

b. Pengumpulan fakta

Proses pengumpulan fakta dilakukan oleh Subbagian Pendataan Informasi Biro Hubungan Masyarakat Sekretariat Daerah Provinsi Riau. Selain itu, Subbagian Pendataan Informasi juga bertugas untuk mempersiapkan bahan-bahan yang akan digunakan untuk memberikan tanggapan dari pemerintah atas krisis yang terjadi sebelum disampaikan oleh Kepala Biro Hubungan Masyarakat Sekretariat Daerah Provinsi Riau.

c. Konferensi Pers

Konferensi pers sebagai salah satu tindakan komunikasi krisis yang dilakukan oleh Biro Hubungan Masyarakat Sekretariat Daerah Provinsi Riau dijalankan oleh
Subbagian Bina Pemberitaan. Kegiatan konferensi pers ini dilakukan untuk memberikan informasi terkini yang disampaikan sebagai bagian dari pernyataan resmi pemerintah. Subbagian Bina Pemberitaan mengurus segala hal yang dibutuhkan dalam pelaksanaan press conference bekerja sama dengan Subbagian Hubungan Pers.

e. Komunikasi reputasi

Komunikasi reputasi dilakukan melalui penyediaan informasi secara berkala melalui publikasi dengan saluran informasi internal dan media massa. Publikasipublikasi tersebut disampaikan terkait dengan tindakan yang telah dilakukan atas krisis yang terjadi. Salah satunya ialah menjalin kerjasama dengan pihak Komisi Pemberantasan Korupsi. Publikasi tersebut disampaikan secara terbuka melalui website resmi biro.

f. Menetapkan juru bicara pemerintahan agar satu suara

Pada Biro Hubungan Masyarakat Sekretariat Daerah Provinsi Riau ditetapkan Kepala Biro yang bertindak sebagai juru bicara pemerintahan berwenang. Kepala Biro Hubungan Masyarakat Sekretariat Daerah Provinsi Riau bertindak sebagai juru bicara 
pemerintahan yang secara resmi menyampaikan seluruh informasi terkait krisis yang terjadi. Di samping itu, juga menjadi narasumber utama yang dituju oleh media massa.

g. Menyediakan banyak saluran komunikasi

Ketika terjadi krisis, penting untuk membuka seluruh saluran komunikasi agar menjadi sarana keterbukaan informasi bagi publik. Adapun saluran komunikasi yang dapat digunakan ialah sebagai berikut.

1) Saluran tatap muka langsung, yakni menyediakan "ruang wartawan".

2) Saluran media massa, yakni pengadaan press release melalui Subbagian Bina Pemberitaan.

3) Media online, yakni melalui website humas.riau.go.id. dan twitter yang dapat diakses dengan nama akun @humasriau.

\section{Strategi Kehumasan Biro Hubungan Masyarakat Sekretariat Daerah Provinsi Riau bagi Penanganan Krisis}

Adapun tahapan strategi penanganan krisis yang dilakukan sesuai dengan strategi kehumasan ialah sebagai berikut. a. Fact Finding

Pada Biro Hubungan Masyarakat Sekretariat Daerah Provinsi Riau, tahap fact finding dilakukan oleh Subbagian Pendataan Informasi. Subbagian Pendataan Informasi melakukan pengumpulan data dan informasi serta mempersiapkan bahan-bahan yang dapat digunakan untuk merespons reaksi publik atas permasalahan dan isu yang terkait dengan pemerintahan. Perolehan informasi dan fakta-fakta terkait dilakukan dengan mengadakan koordinasi bersama Satuan Kerja Perangkat Daerah lainnya; menerima laporan pengaduan masyarakat; menghimpun laporan pengaduan online rakyat; menyeleksi berbagai komentar yang diberikan oleh masyarakat melalui saluran komunikasi terbuka yang disediakan oleh Biro Hubungan Masyarakat Sekretariat Daerah Provinsi Riau seperti akun twitter resmi biro @humasriau dan website resmi biro humas.riau.go.id.

b. Planning and Programming

Tahap planning and programming dilakukan melalui pengadaan upaya perencanaan dan pengambilan keputusan berdasarkan pertimbangan-pertimbangan yang diperoleh melalui tahapan sebelumnya. Pada tahap ini, Biro Hubungan Masyarakat Sekretariat Daerah Provinsi Riau mengidentifikasi 
pesan yang akan disampaikan dengan melakukan persiapan melalui penulisan press release dan menetapkan saluran komunikasi yang dibuka sebagai media ketersediaan informasi bagi masyarakat ketika krisis terjadi. Kepala Biro Hubungan Masyarakat bekerja sama dengan Subbagian Hubungan Pers dan Subbagian Pemberitaan untuk melakukan tahapan tersebut.

\section{c. Action and Communicating}

Tahap action and communicating merupakan tahap dimana Humas mulai mengambil tindakan dan melaksanakan kegiatan beserta program yang telah direncanakan. Pada tahap ini, Biro Hubungan Masyarakat Sekretariat Daerah Provinsi Riau melakukan berbagai kegiatan, yakni melakukan penyebaran press release, pengadaan press conference, pengadaan coffee morning sebagai jalinan hubungan antara pemerintah dan media massa, menyebarluaskan rilis-rilis kegiatan Pemerintah Provinsi Riau, serta selalu aktif mengadakan komunikasi terbuka kepada media massa sebagai upaya pemenuhan informasi masyarakat.

\section{d. Evaluation}

Biro Hubungan Masyarakat Sekretariat Daerah Provinsi Riau melakukan tahap evaluasi setiap semester yakni pada tiap-tiap tiga bulan masa kerja. Evaluasi terkait tindakan komunikasi krisis dilakukan terhadap dua elemen utama, yakni pengelola komunikasi krisis dan tindakan komunikasi krisis. Evaluasi terhadap dua elemen utama tersebut dilakukan berdasarkan laporan pelaksanaan kegiatan yang dilakukan oleh bagian-bagian yang terkait dan dibahas secara lanjut dalam rapat evaluasi biro.

\section{Analisis SWOT dalam Komunikasi Krisis Biro Hubungan Masyarakat} Sekretariat Daerah Provinsi Riau Berdasarkan temuan penelitian, peneliti kemudian melakukan analisis SWOT terhadap tindakan komunikasi krisis Biro Hubungan Masyarakat Sekretariat Daerah Provinsi Riau. Adapun analisis SWOT yang teridentifikasi oleh peneliti dapat dilihat pada tabel 2 
Tabel 2

Analisis SWOT KRISIS PEMPROV RIAU

\begin{tabular}{|c|c|c|}
\hline No. & Analisis SWOT & Keterangan \\
\hline \multirow{4}{*}{1.} & \multirow{4}{*}{ Strengths (Kekuatan) } & Penggunaan sistem one gate communication. \\
\hline & & $\begin{array}{l}\text { Menyediakan saluran tatap muka langsung berupa ruang } \\
\text { khusus wartawan. }\end{array}$ \\
\hline & & $\begin{array}{l}\text { Strategi pesan yang disampaikan yakni rebuilding yang } \\
\text { memperlihatkan keprihatinan. }\end{array}$ \\
\hline & & Saluran media massa disediakan maksimal. \\
\hline \multirow{5}{*}{2.} & \multirow{5}{*}{ Weaknesses (Kelemahan) } & Tidak memiliki crisis plan. \\
\hline & & Posisi Humas saat tahap awal krisis menutup diri. \\
\hline & & Waktu respons krisis tidak segera. \\
\hline & & Tim pengelola komunikasi krisis tidak terstruktur dan kurang. \\
\hline & & Saluran komunikasi online tidak maksimal. \\
\hline 3. & Opportunities (Peluang) & Saluran media online yang berpotensi untuk dikembangkan. \\
\hline 4. & Threats (Ancaman) & Hadirnya juru bicara pihak eksternal. \\
\hline
\end{tabular}

\section{Penutup}

Peneliti menyimpulkan bahwa Biro Hubungan Masyarakat Sekretariat Daerah Provinsi Riau melakukan beberapa strategi komunikasi krisis terkait dengan kasus suap Annas Maamun pada tahun 2014. Adapun strategi komunikasi krisis tersebut ialah menetapkan pengelola komunikasi krisis, menghubungi media massa sesegera mungkin, melakukan pengumpulan fakta, melaksanakan konferensi pers dan komunikasi reputasi, menetapkan Kepala Biro sebagai juru bicara, dan menyediakan banyak saluran komunikasi. Dalam pelaksanaan strategi komunikasi krisis, terdapat beberapa faktor pendukung dan penghambat yang teridentifikasi. Beberapa faktor pendukung tersebut ialah penggunaan sistem one gate communication, menyediakan saluran tatap muka langsung berupa ruang khusus wartawan, strategi pesan yang disampaikan yakni rebuilding yang memperlihatkan keprihatinan, dan saluran media massa yang disediakan secara maksimal. Sedangkan, beberapa faktor penghambat yang teridentifikasi ialah tidak memiliki crisis plan, posisi humas pada saat tahap awal krisis menutup diri, waktu respons krisis tidak segera, tim pengelola komunikasi krisis tidak terstruktur dan kurang, saluran komunikasi online tidak digunakan maksimal, dan hadirnya juru bicara pihak eksternal.

Peneliti juga menyadari bahwa hasil penelitian masih belum sempurna dan memiliki keterbatasan. Adapun keterbatasan yang dimaksud ialah kurangnya kapasitas peneliti untuk menjelaskan tingkat ketepatan tindakan komunikasi krisis yang dilakukan oleh Biro Hubungan Masyarakat Sekretariat Daerah Provinsi Riau. Hal tersebut dikarenakan peneliti hanya berfokus pada tindakan komunikasi krisis yang dilakukan tanpa melihat lebih jauh mengenai ketepatan tindakan komunikasi krisis tersebut. 
Hingga akhirnya hasil penelitian tidak dapat mendeskripsikan apakah tindakan komunikasi krisis yang dilakukan merupakan tindakan yang tepat bagi penyelesaian suatu krisis dan peningkat citra pemerintahan. Oleh karena itu, diharapkan keterbatasan pada penelitian yang dilakukan dapat dikembangkan secara lebih lanjut dan luas oleh peneliti berikutnya.

\section{Daftar Pustaka}

\section{Buku}

Kriyantono, Rachmat. (2015). Public Relations, Issue \& Crisis Management: Pendekatan Critical Public Relations, Etnografi Kritis \& Kualitatif. Jakarta: Prenadamedia Group.

Sukmadinata, Nana Syaodih. (2011). Metode Penelitian Pendidikan. Bandung: PT.

\section{Peraturan}

Peraturan Daerah Provinsi Riau Nomor 1 Tahun 2014 tentang Organisasi Sekretariat Daerah dan Sekretariat Dewan Perwakilan Rakyat Daerah Provinsi Riau.

\section{Koran}

"Mendagri Kembalikan RAPBD Riau," Riau Pos, 11 November 2014.

\section{Internet}

Kuswandi, Rio. 2015. "Gubernur Annas Maamun Dituntut 6 Tahun Penjara." dalam http://regional.kompas.com/rea d/2015/05/25/12304701/Guber nur.Annas.Maamun.Dituntut.6. Tahun.Penjara (akses 23 Maret 2016).

Novitra, Riyan. 2014. "Rekam Jejak Kasus Korupsi Gubernur Riau." dalam https://m.tempo.co/read/news/201 4/o9/28/o63610246/rekam-jejakkasus-korupsi-gubernur-riau (akses 23 Maret 2016). 